\title{
Optimization of nucleosome assembling from histones and model DNAs and estimation of the reconstitution efficiency
}

\author{
M. M. Kutuzov ${ }^{1,2}$, T. A. Kurgina ${ }^{1,2}$, E. A. Belousova ${ }^{1,2}$, S. N. Khodyreva ${ }^{1}$, O. I. Lavrik ${ }^{1,2}$ \\ ${ }^{1}$ Novosibirsk Institute of Chemical Biology and Fundamental Medicine, \\ Siberian Branch of the Russian Academy of Sciences \\ 8, Akademika Lavrentieva Ave., Novosibirsk, Russian Federation, 630090 \\ ${ }^{2}$ Novosibirsk State University \\ 2, Pirogova Str., Novosibirsk, Russian Federation, 630090 \\ lavrik@niboch.nsc.ru
}

\begin{abstract}
Nucleosome core particles (NCPs) are basic units of chromatin organization; they represent the most convenient model system for the study of key DNA-dependent processes. Therefore, a robust method of nucleosome assembly is important for research. To prepare NCPs, purified histones and DNAs with sequences providing strong positioning of DNA relative to histone octamer are commonly used, and a method to control the efficacy of NCP reconstruction is required. Aim. To optimize the procedure for NCP reconstitution from purified histone octamers and different types of synthetic model DNAs and develop a new approach for express analysis of the efficacy of NCP reconstitution. Methods. Dialysis, PAAG, fluorescence measurement using the Eva-Green dye. Results. We first developed a convenient procedure for NCP assembly in a low-salt buffer with a variable DNA-histone ratio at the first stage. Once the optimal ratio was determined, NCPs could be assembled by a slow gradient dialysis. The efficacy of NCP assembly can be estimated directly in the solution using the Eva-Green dye. Conclusions. The efficacy of dye intercalation into DNA duplex was sharply reduced in the nucleosomal context. The main benefits of the proposed approach are the rapid analysis directly in the solution and possibility to use DNAs without any special tags.
\end{abstract}

Ke yw or d s: nucleosome core particle, assembly, chromatin, core histones

\section{Introduction}

The eukaryotic genome exists in a form of chromatin. This supramolecular nucleoprotein complex provides a compaction of billions of nucleotide units of DNA within a nucleus. The primary unit of DNA compaction is nucleosome. Thus, to perform any DNA-dependent process such as replication, repair or transcription it is necessary to affect the chromatin context in whole and to nucleosomes in particular (1-3). There are multiple studies testi-

(C) 2019 M. M. Kutuzov et al.; Published by the Institute of Molecular Biology and Genetics, NAS of Ukraine on behalf of Biopolymers and Cell. This is an Open Access article distributed under the terms of the Creative Commons Attribution License (http://creativecommons.org/licenses/by/4.0/), which permits unrestricted reuse, distribution, and reproduction in any medium, provided the original work is properly cited 
fying the influence of nucleosomal organization on the efficiency of DNA-dependent processes and demonstrating the importance of nucleosomal DNA context to both the nucleosome organization and the process efficacy (1-3). The performance of such investigations implicates the usage of reconstituted nucleosomes with the defined DNA sequence. This entails the necessity to control the efficiency of reconstitution of nucleosome core particles, NCP. Here, we present a method to test the efficacy of NCP reconstitution and to produce NCPs free from naked DNA. Histone octamers used for the NCP formation were purified from chicken erythrocytes, one of the most popular sources of natural histones due to their availability. There is a number of protocols describing the purification of the core histone octamers (4-7). We analyzed them and proposed a combined version with several original modifications. Here, we presented an overview of this protocol.

\section{Materials and Methods}

Erythrocytes purification. All procedures need to be performed at $4^{\circ} \mathrm{C}$ unless otherwise specified. Fresh chicken blood was collected to the anticoagulation buffer at an accurate proportion of $50 \mathrm{ml}$ of blood per $200 \mathrm{ml}$ of the buffer, and then centrifuged for $10 \mathrm{~min}$ at $1500 \mathrm{~g}$. Here and elsewhere it is necessary to avoid the concentration higher than $50 \mathrm{ml}$ of blood/erythrocytes/pellet per $200 \mathrm{ml}$ of the buffer. The buffer contained $30 \mathrm{mM}$ sodium citrate, $\mathrm{pH}$ 7, $0.1 \mathrm{M}$ $\mathrm{NaCl}, 0.1 \mathrm{mM}$ PMSF. Sodium citrate can be replaced by $2500 \mathrm{IU}$ of heparin. Collected blood can be stored for a few hours at $4^{\circ} \mathrm{C}$.

After careful removing of supernatant, the pellet was resuspended in the citrate buffer followed by centrifugation at $1500 \mathrm{~g}$ for $10 \mathrm{~min}$. The washing was repeated twice. The collected pellet was resuspended in sucrose buffer $(60 \mathrm{mM} \mathrm{KCl}, 15 \mathrm{mM} \mathrm{NaCl}, 2 \mathrm{mM}$ spermidine, $340 \mathrm{mM}$ sucrose, $0.1 \mathrm{mM}$ PMSF, $15 \mathrm{mM}$ Tris- $\mathrm{HCl} \mathrm{pH}$ 7.5) with 2.5 mM EDTA, $0.5 \mathrm{mM}$ EGTA, and centrifuged at $1500 \mathrm{~g}$ for $10 \mathrm{~min}$. The washing was repeated twice.

Nuclei purification. The erythrocyte pellet was resuspended in the sucrose buffer with $2.5 \mathrm{mM}$ EDTA, $0.5 \mathrm{mM}$ EGTA, and $0.5 \%$ $\mathrm{NP}-40$ and centrifuged at $1500 \mathrm{~g}$ for $10 \mathrm{~min}$. The washing was repeated until the pellet becomes white. After that, the pellet was resuspended in the sucrose buffer and centrifuged at $1500 \mathrm{~g}$ for $10 \mathrm{~min}$. The washing was repeated twice. The purified nuclei can be kept at $-70^{\circ} \mathrm{C}$ in the storage buffer $(50 \%$ glycerol, $0.15 \mathrm{M} \mathrm{NaCl}, 2 \mathrm{mM}$ spermidine, $0.1 \mathrm{mM}$ EDTA, 0.1mM PMSF, $1 \mathrm{mM}$ DTT, $10 \mathrm{mM}$ Tris- $\mathrm{HCl} \mathrm{pH}$ 8.0).

Histones purification. The nuclei were resuspended in the sucrose buffer with $0.5 \mathrm{mM}$ spermidine and $1 \mathrm{mM} \mathrm{MgCl}, 1 \mathrm{mM} \mathrm{CaCl}_{2}$ to the final concentration of DNA $3 \mathrm{mg} / \mathrm{ml}$. The DNA concentration can be estimated from the absorption of resuspended nuclei at $260 \mathrm{~nm}$. Then MNase was added to a final concentration of 30 units per mg of DNA in the solution. The mixture was incubated for 4 hours at $37^{\circ} \mathrm{C}$ under gentle agitation, transferred on ice, and supplemented with $3 \mathrm{mM}$ EDTA. The pellet was collected by centrifugation at $7000 \mathrm{~g}$ for 10 min, resuspended in the buffer containing 0.25 mM EDTA, pH 8.0, 0.1mM PMSF, stirred for one hour at $4^{\circ} \mathrm{C}$, centrifuged at $7000 \mathrm{~g}$ for $20 \mathrm{~min}$. The supernatant containing mononucleosomes was concentrated via the $10 \mathrm{kDa}$ centrifugal concentrator and diluted with phos- 
phate buffer $\left(25 \mathrm{mM} \mathrm{K}_{2} \mathrm{HPO}_{4}, 25 \mathrm{mM} \mathrm{KH}_{2} \mathrm{PO}_{4}\right)$ with $\mathrm{NaCl}$ to a final concentration of $500 \mathrm{mM}$. The solution was loaded onto HAP-column equilibrated with the buffer consisting of 25 $\mathrm{mM} \mathrm{K}_{2} \mathrm{HPO}_{4}, 25 \mathrm{mM} \mathrm{KH}_{2} \mathrm{PO}_{4}, 500 \mathrm{mM} \mathrm{NaCl}$. The column was washed with the same buffer and with phosphate buffer containing $0.75 \mathrm{M}$ $\mathrm{NaCl}$. The core histones were eluted with phosphate buffer containing $2.2 \mathrm{M} \mathrm{NaCl}$. Pooled fractions can be concentrated via the $10 \mathrm{kDa}$ centrifugal concentrator. The samples supplemented with $0.1 \mathrm{mM}$ PMSF and $40 \%$ glycerol can be stored at $-70^{\circ} \mathrm{C}$. To estimate the concentration of histones the aliquot of purified proteins was diluted in bidistilled water. The absorption at $230 \mathrm{~nm}$ was measured using spectrophotometer. The concentration in $\mathrm{mg} / \mathrm{ml}$ is determined by dividing the absorption value by the extinction coefficient of 4.3.

DNA preparation. The DNA amplification was provided by conventional PCR. The DNA template in concentration $1 \mathrm{ng} / \mu 1$ was supplemented with $0.5 \mu \mathrm{M}$ primers and standard PCR buffer components. The program for amplification:

$95^{\circ} \mathrm{C} 3 \mathrm{~min}$

$94^{\circ} \mathrm{C} 15 \mathrm{sec}$

$65^{\circ} \mathrm{C} 15 \mathrm{sec}$ (the decrement of $1^{\circ} \mathrm{C}$ per cycle from $65^{\circ} \mathrm{C}$ to $61^{\circ} \mathrm{C}$ )

$72^{\circ} \mathrm{C} 10 \mathrm{sec}$

5 cycles

$94^{\circ} \mathrm{C} 15 \mathrm{sec}$

$60^{\circ} \mathrm{C} 15 \mathrm{sec}$

$72^{\circ} \mathrm{C} 10 \mathrm{sec}$

15 cycles

$4^{\circ} \mathrm{C}$ hold
To remove the excess of primers the samples were treated with ExoI exonuclease by supplemented with $10 \mathrm{x}$ buffer containing $67 \mathrm{mM} \mathrm{MgCl} 2,10 \mathrm{mM}$ DTT, $670 \mathrm{mM}$ glycine$\mathrm{KOH} \mathrm{pH} 9.5$ to $1 \mathrm{x}$ and $0.1 \mathrm{U} / \mu 1$ ExoI. The DNA was precipitated by addition of $\mathrm{NaOAc}$ up to $0.3 \mathrm{M}$ and supplemented by ethanol up to $70 \%$ and incubated at $-20^{\circ} \mathrm{C}$ for 1 hour. After centrifugation at $14000 \mathrm{~g}$ for $10 \mathrm{~min}$ the pellet was washed twice with $70 \%$ ethanol followed by dissolution in bidistilled water. The concentration of DNA was measured using spectrophotometer at $260 \mathrm{~nm}$.

Nucleosome assembling. Quick-time reconstitution. In this approach either radioactive- or fluorescent-labelled DNA should be used. The DNA in final concentration of $0.1 \mu \mathrm{M}$ was mixed with histones in different concentrations in low-salted buffer $(10 \mathrm{mM} \mathrm{NaCl}, 0.2 \mathrm{mM}$ EDTA, $5 \mathrm{mM}$ beta mercaptoethanol, $0.1 \%$ NP-40, $10 \mathrm{mM}$ Tris-HCl pH 7.5), incubated for $15 \mathrm{~min}$ at $37^{\circ} \mathrm{C}$ and analyzed by $4 \%$ PAGE under non-denaturing conditions. The minimal DNA:histone ratio corresponding to the mixture with no naked DNA should be used for preparative reconstitution.

Preparative reconstitution. The DNA and histones should be taken in the concentrations determined under "quick-time reconstitution", mixed in the high-salted buffer containing $2 \mathrm{M}$ $\mathrm{NaCl}$, and dialyzed against the buffer with gradient of $\mathrm{NaCl}$ from $2 \mathrm{M}$ to $250 \mathrm{mM}$ during 6 hours at $4^{\circ} \mathrm{C}$ with gentle stirring. Then the probes were dialyzed against the buffer with $10 \mathrm{mM} \mathrm{NaCl}$ overnight at $4^{\circ} \mathrm{C}$ with gentle stirring.

Analysis of nucleosome reconstitution using Eva-Green dye. The samples of $10 \mu 1$ containing $50 \mathrm{mM} \mathrm{NaCl}, 10 \mathrm{mM}$ DTT, $50 \mathrm{mM}$ Tris- 
$\mathrm{HCl} \mathrm{pH}$ 8.0, $50 \mathrm{nM}$ nucleosome (the concentration was defined by nucleic acid component) and $0.5 \mathrm{x}$ Eva-Green (Biotium) were placed to the 384-well round bottom microplate to estimate the fluorescence intensity. The measurement was performed in microplate reader CLARIOstar (BMG Labtech) at $520 \mathrm{~nm}$. The average value of five independent measurements was normalized to fluorescent level of naked dsDNA and analyzed using MARS Data Analysis Software (BMG Labtech).

\section{Results and Discussion}

The design of DNA substrates was based on nucleotide sequences named clones 603 and 605 that were constructed and published by Lowary and Widom (8). The length of these DNA duplexes is 147 nucleotides, which ex- actly corresponds to the "core" part of nucleosomes in vivo. The feature of these sequences consists in the precise positioning of the histone octamer on DNA during the formation of NCP. Additionally, the histone octamer has a high affinity to these DNAs. Thus, along with $5 \mathrm{~S}$ ribosomal cDNA, these DNAs are widely used in the assembling of NCP in vitro $(9,10)$.

First, the preparative amounts of plasmid DNA encoding the 603 and 605 sequences were produced in E. coli strain according to a standard protocol (11). The DNA was isolated, and the regions of interest were amplified by PCR. The PCR primers were chemically synthesized to obtain the final DNA containing or not the discriminant mark in the 5'-part of the DNA duplex (Figure 1, A). Such approach permits to produce the target DNA constructs

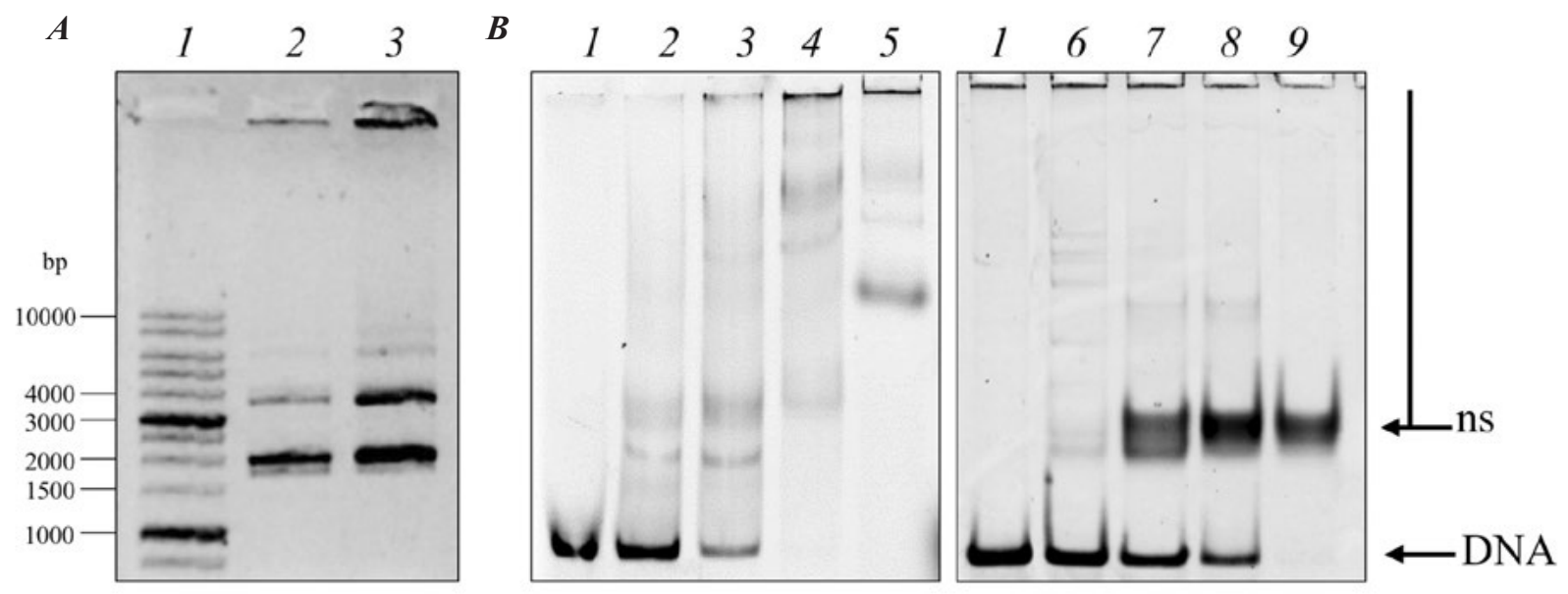

Fig. 1. A - Electrophoretic analysis of PCR products. The electrophoretic mobility of the plasmid DNA encoding the Widom clones 603 and 605 in $1 \%$ agarose gel in non-denaturing conditions with SYBR Green-1 staining. Lane 1 - marker DNAs, lane 2 - clone 603, 3 - clone 605. B - Nucleosome assembling. The electrophoretic mobility of 5'-FAM labelled products after the process of NCP reconstruction from model FAM-DNA and histone octamers in $4 \%$ PAAG under non-denaturing conditions. Lane 1 - free DNA; lanes 2-5 - samples with an increasing ratio of DNA to proteins from 1:0.3 to 1:0.6 with the increment of 0.1 assembled by quick-time method; lanes 6-9 NCP assembled by gradient dialysis with the ratio of DNA to proteins from 1:0.2 to 1:0.5 with the increment of 0.1. Ns - nucleosome particles, DNA — naked DNA. 
with the specific damage at the defined position or special label at the 5 '-end of the resulting DNA. This is important to study various mechanisms of DNA repair in context of NCP. Some experimental approaches using reconstituted nucleosomes are sensitive to contamination by single-stranded DNA. The nucleosomal DNAs prepared by PCR often contain the unspent primer molecules. We used treatment with Exonuclease I to remove any singlestranded DNAs including PCR primers. After the ExoI treatment and DNA precipitation with ethanol the amplicons were used to obtain the target model NCPs.

At the next stage, we worked out the procedure for nucleosome assembling using purified histone octamers and amplified model DNAs. First of all, to assemble the nucleosomes correctly, the attention should be paid to the ratio of concentrations of DNA and histone octamer samples. Basically, this ratio should be equimolar to escape, on the one hand, the excess of free DNA in the final sample solution, and on the other hand, the formation of high-molecular weight DNA-protein complexes upon histone abundance. However, due to highly basic nature of the histones it is impossible to determine precise concentration of protein in the samples using standard Bradford protocol. Therefore, the absorbance measurements at $230 \mathrm{~nm}$ are commonly used, but mostly small molecules absorb at this wavelength. Thus, it is necessary to select the DNA-protein ratio in mixture for each sample. We proposed the fast assembling of NCPs in low-salted nucleosome buffer under titration of the DNA-histone ratio. The analysis in non-denaturing $4 \%$ PAAG allows selection of the nucleic acid to protein proportion providing the correct assembling of
NCP (Fig. 1, B). Then the octamers were initially mixed with DNA in the buffer containing $2 \mathrm{M} \mathrm{NaCl}$ and subjected to a gradient dialysis at $+4^{\circ} \mathrm{C}$ for about 6 hours to decrease the salt concentration to $250 \mathrm{mM}$. Finally, the NCP solution was dialyzed overnight against the buffer with $10 \mathrm{mM} \mathrm{NaCl}$ at $4^{\circ} \mathrm{C}$. The efficiency of nucleosome assembling was analyzed by classical method with an electrophoretic separation in $4 \%$ PAAG under non-denaturing conditions. In Fig. 1, B it is presented an example of electrophoregram of the products of the nucleosome assembling after the selection of the DNA-protein ratio for preparative reconstruction of NCP using DNA with the 5'-fluorescent label.

This standard approach has an obvious disadvantage as far as it does not allowed the estimation of percent of out-of-nucleosome DNA directly in the solution under equilibrium conditions. This problem could be solved by utilizing an external fluorescent dye in the solution after the assembling procedure. Accordingly, we suggested an alternative approach for analyzing the efficiency of nucleosome assembling in solution using the EvaGreen dye. It is an intercalating dye, the specific characteristic of which is to effectively interact only with double-stranded DNA (12). The fluorescent signal from Eva-Green is nonessential by itself due to self-extinguishing, but its level dramatically increased upon dsDNA binding. Noteworthy, at the formation of DNA-protein complex the fluorescent signal can be obtained from all DNA forms, which are accessible for Eva-Green intercalation. In this case, at the formation of compact NCP the efficiency of dye intercalation should sharply reduce and the consequent fluorescent level of 


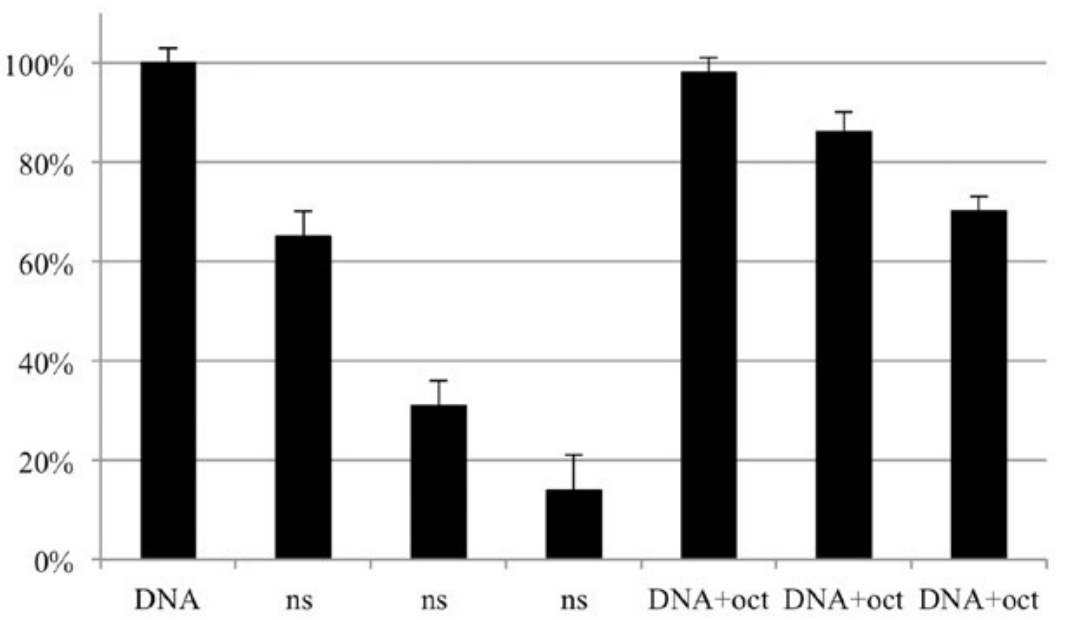

Fig. 2. The level of fluorescence signals at different ways of nu- cleosome assembling. Y-axis is represented in relative units, where the fluorescent level of dsDNA/ Eva-Green complex was taken as $100 \%$. The bars on the $\mathrm{X}$-axis are the following: DNA - the fluorescence of dsDNA/Eva-Green complex; ns - the fluorescence of nucleosome/Eva-Green complexes after slow assembling at the ratio of DNA:histones 1:0.3, 1:0.4, and 1:0.5; DNA+oct (octamer of histones) — the fluorescence of histones/DNA/Eva-Green complexes after quick-time reconstitution of the components at the ratio of DNA:histones 1:0.5, 1:0.75, and $1: 1$. The results are the mean $\pm \mathrm{SD}$, $\mathrm{n}=5$.
DNA/Eva-Green complex should decrease. Indeed, in the experiments we obtained a reduction of the fluorescent level of DNA/EvaGreen consisting of nucleosomes compared to the initial DNA/Eva-Green fluorescence. Whereas the change in fluorescent level at the quick-time reconstitution was significantly lower (Fig. 2). It should be mentioned that these results are in full agreement with the data obtained by electrophoretic analysis under non-denaturing conditions.

Therefore, we suggested the optimized approach to track the NCP assembly. According to it, the quick-time assembling of NCP in low-salted buffer at the first stage allows the selection of precise DNA-histone ratio. After that the quality of slow nucleosome assembling could be estimated directly in the solution. Moreover, it does not require the presence of any labels in DNA to monitor the nucleosome formation during the preparative reconstitution. The main advantages of this approach are the performance of the study in the solution, which is fast and convenient, and the opportunity to use different types of DNA required for further research procedures.

\section{Ascknowlegement}

The work was supported by RSF grant 17-7420075.

\section{REFERENCES}

1. MacAlpine DM, Almouzni G. Chromatin and DNA replication. Cold Spring Harb Perspect Biol. 2013;5(8):a010207.

2. Balliano AJ, Hayes $J J$. Base excision repair in chromatin: Insights from reconstituted systems. DNA Repair (Amst). 2015;36:77-85.

3. Lee J, Crickard JB, Reese JC, Lee TH. Singlemolecule FRET method to investigate the dynamics of transcription elongation through the nucleosome by RNA polymerase II. Methods. 2019. pii: S10462023(18)30293-7.

4. Osterman LA. Chromatography of proteins and nucleic acids. Moscow: Nauka, 1985. 536 p.

5. Simon $R H$, Felsenfeld $G$. A new procedure for purifying histone pairs $\mathrm{H} 2 \mathrm{~A}+\mathrm{H} 2 \mathrm{~B}$ and $\mathrm{H} 3+\mathrm{H} 4$ from 
Optimization of nucleosome assembling from histones and model DNAs and estimation of the reconstitution efficiency

chromatin using hydroxylapatite. Nucleic Acids Res. 1979;6(2):689-96.

6. Schnitzler GR. Isolation of histones and nucleosome cores from mammalian cells. Curr Protoc Mol Biol. 2001; Chapter 21:Unit 21.5.

7. Peterson CL, Hansen JC. Chicken erythrocyte histone octamer preparation. CSH Protoc. 2008; 2008:pdb.prot5112.

8. Lowary PT, Widom J. New DNA sequence rules for high affinity binding to histone octamer and sequence-directed nucleosome positioning. J Mol Biol. 1998;276(1):19-42.

9. Cannan WJ, Tsang BP, Wallace SS, Pederson DS. Nucleosomes suppress the formation of doublestrand DNA breaks during attempted base excision repair of clustered oxidative damages. J Biol Chem. 2014;289(29):19881-93.

10. Hinz JM. Impact of abasic site orientation within nucleosomes on human APE1 endonuclease activity. Mutat Res. 2014;766-767:19-24.

11. Green RM, Sambrook J. Molecular cloning: a laboratory manual. New York: Cold Spring Harbor, 4th edition. 2012: 2028

12. Mao F, Leung WY, Xin X. Characterization of EvaGreen and the implication of its physicochemical properties for qPCR applications. BMC Biotechnol. 2007;7:76.

\section{Оптимізація протоколу збірки нуклеосом з використанням гістонів і модельних ДНК- дуплексів і оцінка ефективності процесу реконструкції}

М. М. Кутузов, Т. А. Кургіна, С. А. Белоусова, С. Н. Ходирева, О. І. Лаврік

Нуклеосомна корова частка, НКЧ, являє собою зручну модельну систему для вивчення ключових ДНКзалежних процесів, оскільки є елементарною одиницею структури хроматину. Саме тому основним завданням представленого дослідження було створення універсального методу збірки нуклеосом. Для реконструкції НКЧ використовуються очищені гістони і ДНК-структури з певними послідовностями, що забезпечують чітке позиціонування ДНК відносно октамера гістонів. Це вимагає наявності спо- собу контролю ефективності реконструкції НКЧ. Мета. Оптимізувати процедуру реконструкції НКЧ 3 очищених октамер гістонів і різних типів синтезованих модельних ДНК і запропонувати підхід для експрес-аналізу ефективності цього процесу. Методи. Діаліз, поділ в ПААГ, вимір флуоресценції 3 використанням барвника Eva-Green. Результати. Ми розробили зручну процедуру складання НКЧ в слабо сольовому буфері із змінним співвідношенням ДНК-гістони на першому етапі. Після визначення оптимального співвідношення реконструкція НКЧ може бути проведена за допомогою повільного градиентного діалізу. На цьому етапі ефективність процесу може бути оцінена безпосередньо в розчині 3 використанням барвника Eva-Green. Висновки. Було показано, що ефективність интеркаляции барвника в дуплекс ДНК в контексті нуклеосоми різко знижується. До основних переваг запропонованого підходу можна віднести швидкий аналіз суміші безпосередньо в розчині і можливість використання ДНК, що не містять будь-яких спеціальних міток.

К л юч о в і с л о в а: збірка нуклеосомних корових частинок, хроматин, корові гістони

\section{Оптимизация протокола сборки нуклеосом с использованием гистонов и модельных ДНК-дуплексов и оценка эффективности процесса реконструкции}

М. М. Кутузов, Т. А. Кургина, Е. А, Белоусова, С. Н. Ходырева, О. И. Лаврик

Нуклеосомная коровая частица, НКЧ, представляет собой удобную модельную систему для изучения ключевых ДНК-зависимых процессов, поскольку является элементарной единицей структуры хроматина. Именно поэтому основной задачей представленного исследования было создание универсального метода сборки нуклеосом. Для реконструкции НКЧ используются очищенные гистоны и ДНК-структуры с определенными последовательностями, обеспечивающими четкое позиционирование ДНК относительно октамера гистонов. Это требует наличия способа контроля эффективности реконструкции НКЧ. Цель. Оптимизировать процедуру реконструкции НКЧ из очищенных октамеров гистонов и различных типов синтезирован- 
ных модельных ДНК и предложить подход для экспресс-анализа эффективности этого процесса. Методы. Диализ, разделение в ПААГ, измерение флуоресценции с использованием красителя Eva-Green. Результаты. Мы разработали удобную процедуру сборки НКЧ в слабо солевом буфере с изменяемым соотношением ДНК-гистоны на первом этапе. После определения оптимального соотношения реконструкция НКЧ может быть проведена с помощью медленного градиентного диализа. На этом этапе эффективность процесса может быть оценена непосредственно в растворе с использованием красителя Eva-Green.
Выводы. Было показано, что эффективность интеркаляции красителя в дуплекс ДНК в контексте нуклеосомы резко снижается. К основным преимуществам предложенного подхода можно отнести быстрый анализ смеси непосредственно в растворе и возможность использования ДНК, не содержащих каких-либо специальных меток.

К л юч е в ы е с л о в а: сборка нуклеосомных коровых частиц, хроматин, коровые гистоны.

Received 02.01.2019 